\title{
UPAYA MENINGKATKAN KEMAMPUAN MENULIS PUISI DENGAN MENGGUNAKAN MODEL CIRC KELAS V SD NEGERI 104247 TANJUNG MULIA T.A 2017/2018
}

\author{
Erlinda Simanungkalit ${ }^{1}$, Ayu Listian Tarigan ${ }^{2}$ \\ Surel: erlindasimanungkalit@gmail.com
}

\begin{abstract}
The purpose of this study was to improve the ability to write poetry of students on Indonesian language lessons for the subject matter of writing poetry with the application of the CIRC method (Cooperative, Integrated, Reading, And Composition). Data collection techniques used were observation and tests. The technical analysis of the data used is observation. The results of the Hypothesis Test can be concluded that the use of the CIRC method (Cooperative, Integrated, Reading, And Composition) can improve students' poetry writing skills in Indonesian language learning especially the subject matter of writing poetry.
\end{abstract}

Keywords: Writing Ability, CIRC

\begin{abstract}
ABSTRAK
Tujuan penelitian ini adalah untuk meningkatkan kemampuan menulis puisi siswa pada pelajaran Bahasa Indonesia untuk materi pokok menulis puisi dengan penerapan metode CIRC (Cooperative, Integrated, Reading, And Composition). Teknik pengumpulan data yang digunakan adalah observasi dan tes. Teknis analisis data yang digunakan adalah observasi. Hasil Uji Hipotesis dapat disimpulkan bahwa penggunaan metode CIRC (Cooperative, Integrated, Reading, And Composition) dapat meningkatkan kemampuan menulis puisi siswa pada pembelajaran Bahasa Indonesia khususnya materi pokok menulis puisi.
\end{abstract}

Kata Kunci: Kemampuan Menulis, $C I R C$

\section{PENDAHULUAN}

Bahasa adalah alat komunikasi yang digunakan oleh setiap individu dalam kehidupan sehari-hari. Bahasa juga dikatakan sebagai satuan ujaran yang dihasilkan oleh alat ucap manusia sebagai lambang bunyi yang bersifat arbitrer dan memiliki satuan arti yang lengkap dengan bahasa itulah manusia dapat saling berinteraksi satu sama lainnya.
Interaksi itu sendiri adalah berkomunikasi.

Kita sadari bahwa penguasaan bahasa sangat rendah baik bagi siswa maupun guru. Dan di dalam proses pembelajaran kurang mendorong terjadinya pengembangan siswa yang dinamis. Guru sebagai salah satu sumber belajar berkewajiban menyediakan lingkungan belajar yang kreatif bagi kegiatan belajar siswa di 
dalam kelas. Tetapi guru masih menggunakan metode ceramah tentunya tidak akan memacu siswa kreatif dalam menulis, tetapi membuat siswa merasa bosan dan berakibat pada sulitnya siswa untuk memahami pelajaran Bahasa Indonesia khususnya pada materi pokok menulis puisi.

Berdasarkan pengamatan di kelas V SD Negeri 104247 Tanjung Mulia, hasil observasi yang didapat menunjukkan bahwa hasil belajar siswa masih tergolong rendah. Berdasarkan daftar kumpulan nilai dan prestasi siswa kelas $\mathrm{V}$ menunjukkan rata-rata nilai Bahasa Indonesia dalam menulis dari 23 jumlah siswa, hanya $21 \%$ atau 5 orang yang mampu mendapat nilai dibawah 65, sedangkan $79 \%$ atau 18 orang mendapat nilai dibawah 65 .

Dari data tersebut terlihat secara jelas bahwa kemampuan menulis siswa kelas V SD Negeri 104247 Tanjung Mulia masih sangat rendah. Rendahnya hasil belajar siswa ini ditandai dengan banyaknya siswa yang belum mampu menulis puisi dengan baik dan benar, masih banyak terdapat kesalahan dalam menentukan tema, dan kurangnya kosa kata yang dikuasai siswa yang mengakibatkan puisi tersebut tidak menarik. Dilihat dari pihak guru dalam mengajarkan siswa pada materi menulis dalam menulis puisi belum memuaskan.

Peneliti menemukan bahwa kesulitan siswa dalam menulis puisi disebabkan, antara lain oleh rendahnya tingkat penguasaan siswa terhadap kosa kata Bahasa Indonesia dan penyajian pembelajaran menulis puisi yang kurang menarik oleh guru. Siswa yang telah banyak memiliki perbendaharaan kata, ia akan dapat peningkatan. Namun, bagi siswa yang kurang memiliki perbendaharaan kata, hal ini menjadi masalah baginya. Sehingga sulit untuk mencapai kompetensi dasar yaitu menulis puisi bebas dengan pilihan kata yang tepat.

Situasi tersebut menuntut guru untuk mencari model pembelajaran yang tepat, guna merangsang dan meningkatkan kemampuan siswa dalam menulis puisi. Model pembelajaran CIRC (Cooperative, Integrated, Reading, And Composition) yaitu kooperatif terpadu membaca dan menulis merupakan model pembelajaran yang lebih cocok dan tepat di aplikasikan pada mata pelajaran Bahasa Indonesia.

Secara sederhana CIRC (Cooperative, Integrated, Reading, And Composition) dapat diartikan sebagai pembelajaran terpadu setiap siswa bertanggung jawab terhadap tugas kelompok. Setiap anggota kelompok saling mengeluarkan ideide untuk memahami suatu konsep dan menyelesaikan tugas, sehingga terbentuk pemahaman dan pengalaman belajar yang lama.

Teknik analisis data menggunakan presentase ketuntasan belajar dengan rumus: $\mathrm{KB}=\hat{\mathrm{A}} \hat{\mathrm{A}} \hat{\mathrm{A}}$ $x \hat{A} 100 \%$, dimana $\mathrm{KB}=$ Ketuntasan Belajar, $\mathrm{T}=$ Jumlah skor yang 
diperoleh siswa, $\mathrm{Tt}=$ Jumlah skor total. Analisis data menunjukan bahwa hasil belajar saat dilakukan tindakan mengalami peningkatan. Peningkatan tersebut dapat dilihat dari hasil belajar siswa secara klasikal pada siklus I adalah 64,4 \% dan pada siklus II adalah $88,8 \%$.

Rendahnya hasil belajar siswa diduga karena siswa yang tidak aktif dan model pembelajaran yang monoton menyebabkan perlunya penelitian yang bertujuan meningkatkan hasil belajar siswa melalui pembelajaran model CIRC. Tujuan khusus penelitian adalah mendeskripsikan: (1) Keterampilan guru (2) peningkatan hasil belajar, (3) aktivitas siswa, (4) respon siswa terhadap pembelajaran. Penelitian ini penelitian tindakan kelas yang terdiri 3 siklus. Perangkat dan instrumen yang digunakan adalah RPP, handout, LKS, THB, lembar observasi keterampilan guru mengelola pembelajaran, aktivitas siswa, dan lembar respon siswa. Data diperoleh dari hasil tes, observasi, angket, dan dokumentasi. Data dianalisis dengan teknik persentase.

\section{METODE PENELITIAN}

Jenis penelitian ini adalah Penelitian Tindakan Kelas (PTK) yang merupakan suatu model peneltian yang dikembangkan di kelas. Menurut Dewi (2015:9) menyatakan "kelas yang dimaksud dalam hal ini bukan berarti kelas fisik atau ruang, tetapi kegiatan pembelajaran dalam suatu mata pelajaran untuk melayani sejumlah peserta didik di dalam proses pendidikan dan pengajaran ".

Penelitian dilakukan pada siswa kelas V SD Negeri 104247 Tanjung Mulia semester genap T.A 2017/2018. yang beralamat di Jalan Galang Desa Tanjung Mulia Kecamatan Pagar Merbau Kabupaten Deli Serdang.

Subjek penelitian ini adalah siswa kelas V SD Negeri 104247 Tanjung Mulia. Dari 23 orang siswa dengan jumlah siswa laki-laki 12 dan jumlah siswa perempuan 11. Objek penelitian ini model pembelajaran CIRC (Cooperative, Integrated, Reading, And Composition) dalam meningkatkan kemampuan menulis puisi siswa pada mata pelajaran Bahasa Indonesia di kelas V SD Negeri 104247 Tanjung Mulia.

\section{HASIL DAN PEMBAHASAN}

Penelitian mulai dilaksanakan pada tanggal 27 Maret 2018 hingga 30 Mei 2018. Sebelum penelitian dilakukan peneliti meminta izin terlebih dahulu kepada Kepala Sekolah dan Guru Kelas V. Peneliti juga menjelaskan prosedur pelaksanaan penelitian dan meminta ketersediaan guru untuk melakukan observasi pada peniliti saat melakukan penelitian. Untuk mengobservasi siswa dibantu oleh teman sejawat.

Penelitian

berbentuk

Penelitian Tindakan Kelas dengan menggunakan metode pembelajaran CIRC (Cooperative, Integrated, Reading, And Composition) untuk meningkatkan kemampuan menulis 
puisi siswa yang dilakukan di SD Negeri 104247 Tanjung Mulia Tahun Pelajaran 2017/2018. Penelitian ini terdiri dari dua siklus, dimana siklus pertama dilaksanakan dalam dua kali pertemuan dan siklus ke dua dilaksanakan dua kali pertemuan. Penelitian ini hanya dilaksanakan di kelas V dimana setelah dilakukan observasi ternyata memiliki permasalahan berupa rendahnya kemampuan menulis puisi siswa dalam kegiatan pembelajaran di sekolah.

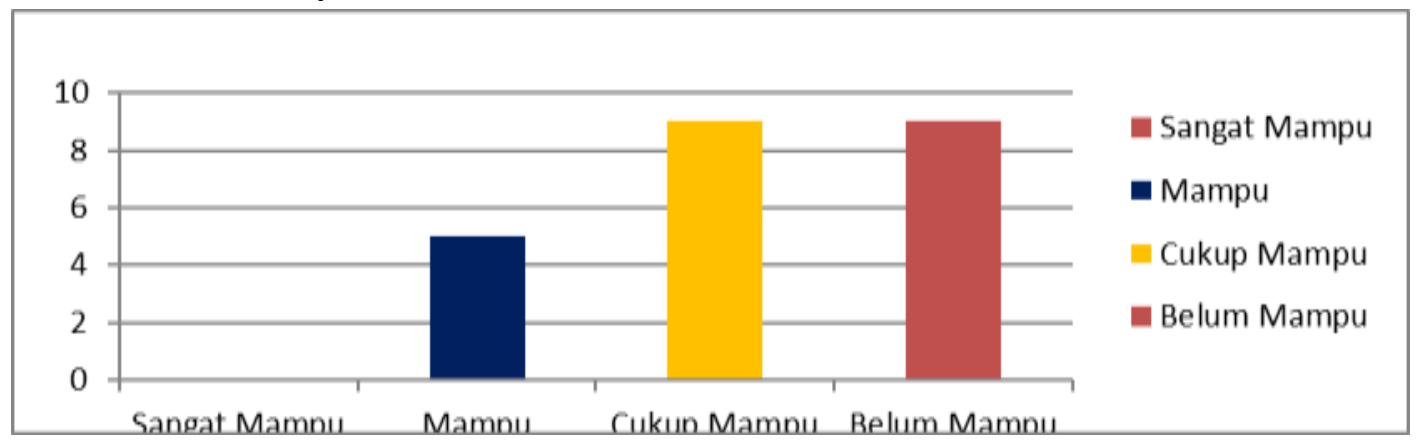

\section{Diagram 4.1 Persentase Kemampuan Menulis Siswa berdasarkan lembar Observasi pada Siklus I Pertemuan 1}

Dari data hasil observasi dapat diketahui bahwa kemampuan menulis siswa kelas $\mathrm{V}$ yaitu sedikit meningkat dari kondisi awal, akan tetapi perubahan yang terjadi belum sesuai dengan harapan. Adapun hasil yang diperoleh adalah belum ada siswa yang Sangat Mampu dalam menulis, terdapat 5 orang siswa $(21,73 \%)$ memperoleh kriteria

Proses pembelajaran yang dilaksanakan pada siklus I pertemuan 1 dapat dikategorikan kurang maksimal. Hasil observasi terhadap kemampuan menulis siswa dalam mempelajari puisi masih tergolong rendah. Hal ini terbukti dari observasi yang dilakukan terhadap kemampuan menulis siswa dengan total 1315 dari nilai rata-rata 57,17 menunjukkan bahwa dari 23 orang siswa memiliki kategori kemampuan
Mampu, 9 orang siswa $(39,13 \%)$ memperoleh kriteria Cukup Mampu dan 9 orang siswa $(39,13 \%)$ yang memperoleh kriteria Belum Mampu.

$\mathrm{P}=\frac{f}{N} \times 100 \%$

$\mathrm{P}=\frac{5}{23} \times 100 \%$

$\mathrm{P}=21,73 \%$ (Kriteria Belum)

menulis puisi yang masih kurang dan hasil observasi kegiatan guru (Peneliti) dengan total skor 77,5. Dari data observasi pada siklus I pertemuan 1 diketahui bahwa kemampuan menulis puisi siswa dan kegiatan pembelajaran yang dilakukan oleh guru belum mencapai nilai minimal yang telah ditentukan yakni sebesar 85 . 
Oleh karena itu, Peneliti merasa perlu melakukan perbaikan pada pertemuan kedua untuk meningkatkan kemampuan menulis puisi siswa yang diharapkan akan berdampak baik terhadap kemampuan menulis siswa pada materi menulis puisi.

Adapun hal-hal yang perlu diperbaiki pada pelaksanaan siklus 1 pertemuan 2 yakni : 1. Siswa masih kurang tekun dalam menulis puisi karena guru masih kurang menjelaskan dengan baik materi sehingga banyak siswa yang mengganggu teman sewaktu belajar. 2. Siswa belum patuh dalam mengerjakan perintah dan pengerjaan tugas yang diberikan guru karena guru belum dapat melaksanakan metode pembelajaran CIRC (Cooperative, Integrated, Reading, And Composition) dengan baik. 3. Masih banyak siswa yang bermain di dalam kelas dan tidak memperhatikan pelajaran yang diberikan guru karena guru kurang memperhatikan kegiatan yang dilakukan siswa sewaktu guru menerangkan, guru hanya sibuk menerangkan materi tanpa mengetahui keadaan di dalam kelas. 4. Siswa masih kurang aktif dalam proses belajar karena guru kurang melibatkan siswa dalam kegiatan pembelajaran. 5. Siswa kurang memahami materi menulis puisi karena guru kurang memberi latihan kepada siswa.

\section{Pembahasan Hasil Penelitian}

Penelitian yang dilaksanakan di SD Negeri No. 104247 Tanjung Mulia bertujuan untuk mengetahui apakah dengan menggunkan metode CIRC (Cooperative, Integrated, Reading, And Composition) dapat meningkatkan kemampuan menulis siswa pada mata pelajaran Bahasa Indonesia di kelas V. Berdasarkan hasil pengamatan awal sebelum dilakukan pembelajaran dengan menggunakan metode CIRC (Cooperative, Integrated, Reading, And Composition), menunjukkan bahwa siswa masih kurang memiliki kemampuan dalam menulis puisi.

\begin{tabular}{lcr}
\multicolumn{2}{r}{ Selanjutnya } & $\begin{array}{r}\text { dilakukan } \\
\text { tindakan } \\
\text { dengan }\end{array}$ \\
metode & CIRC & (Cooperative, \\
Integrated, & Reading, And
\end{tabular}
Composition), siklus I dilakukan sebanyak 2 kali pertemuan pada materi pokok menulis puisi. Selama pembelajaran berlangsung, guru kelas selaku mitra kolaborasi bersama teman sejawat melakukan pengamatan tentang kegiatan pembelajaran yang dilakukan oleh peneliti. Hasil pengamatan peneliti menunjukkan adanya peningkatan kemampuan menulis puisi siswa dibandingkan sebelum dilaksanakannya siklus I.

Hingga pertemuan kedua siklus I kemampuan menulis siswa tergolong belum. Hasil analisis yang dilakukan menunjukkan bahwa dalam pertemuan pertama pada siklus I terdapat belum ada siswa yang memperoleh kriteria sangat 
mampu menulis, 5 orang siswa $(21,73 \%)$ yang mampu menulisnya, 9 orang siswa $(39,13 \%)$ yang cukup mampu menulisnya, 9 orang siswa $(39,13 \%)$ yang belum mampu menulis.

Hingga pertemuan kedua siklus I masih terdapat 1 orang siswa $(4,34 \%)$ yang sangat mampu menulis, 9 orang siswa $(39,13 \%)$ yang memiliki kriteria mamp, 13 orang siswa $(56,52 \%)$ yang memiliki kriteria cukup mampu dan sudah tidaka ada lagi siswa yang belum mampu menulis. Hal ini menunjukkan bahwa setelah diterapkan metode CIRC (Cooperative, Integrated, Reading, And Composition) pada siklus I, siswa telah memiliki kemampuan menulis namun masih belum maksimal dalam mengikuti kegiatan pembelajaran yang dilakukan peneliti. Karena itu peneliti memutuskan untuk terus meningkatkan kemampuan menulis siswa dengan melakukan tindakan pada siklus II.

Siklus II dilakukan dengan
lebih menekankan $\begin{array}{r}\text { tentang } \\ \text { pengawasan dan mengarahkan }\end{array}$
seluruh siswa untuk aktif dalam
melakukan kegiatan pembelajaran
dengan lebih baik dan pemberian
arahan kepada siswa untuk lebih
aktif dalam mengikuti kegiatan
pembelajaran. Dan kepada siswa
yang belum aktif dalam mengikuti
kegiatan pembelajaran pada siklus I
lebih diarahkan supaya dapat aktif
dalam mengikuti pembelajaran

dengan baik. Selama melakukan tindakan pada siklus II yang juga menggunakan metode CIRC (Cooperative, Integrated, Reading, And Composition), peneliti dibantu guru kelas dan teman sejawat tetap melakukan pengamatan sesuai format observasi yang tersedia. Hasil pengamatan menunjukkan adanya peningkatan pada kemampuan menulis siswa.

Selama siklus II siswa tampak lebih memiliki rasa ingin tahu dalam mengikuti pembelajaran. Berdasarkan hasil analisis pada siklus II pertemuan 1 terdapat 6 orang siswa $(26,08 \%)$ yang sangat mampu menulis, 6 orang siswa (26,08\%) yang mampu menulis, 11 orang siswa $(47,82 \%)$ dan sudah tidak ada lagi ssiwa yang belum mampu menulis. Hal ini menunjukkan bahwa siswa sudah mampu dalam kegiatan pembelajaran. Data pada siklus II pertemuan 2, kemampuan menulis siswa menunjukkan hasil yang sangat memuaskan dimana terdapat 12 orang siswa $(52,17 \%)$ sangat mampu dalam menulis puisi dan 11 orang siswa $(47,82 \%)$ mampu menulis puisi, sudah tidak ada lagi siswa yang Cukup Mampu dan belum mampu menulis puisi. Hal itu tentu saja membuktikan bahwa dengan menggunakan metode CIRC ( Cooperative, Integrated, Reading, And Composition) kemampuan menulis siswa dapat ditingkatkan. Hal tersebut juga diperkuat dengan pemberian Tes awal siswa yang 
memiliki jumlah nilai 1.125 dengan nilai rata-rata 48,91 mengalami peningkatan setelah menggunakan metode CIRC ( Cooperative, Integrated, Reading, And Composition) menjadi 1.890 dengan nilai rata-rata 82,17 .

Dengan demikian berdasarkan jurnal Mersty Elisabeth Rindengan "Peningkatan Kemampuan Menulis Puisi Dengan Pendekatan Kontekstual Melalui Teknik CIRC”, Jurnal Pendidikan Bahasa dan Sastra, Vol.16, No.1, bahwa pembelajaran menulis puisi siswa dengan CIRC sangat dibutuhkan dalam pembelajran di SD Karena penedekatan kontekstual mencitakan suasana yang menyenangkan dalam belajar. hasil penemuan dan analisis data penelitian yang diperoleh maka dapat disimpulkan bahwa penggunaan metode CIRC (Cooperative, Integrated, Reading, And Composition) dapat meningkatkan kemampuan menulis siswa kelas V di SD Negeri No. 104247 Tanjung Mulia dalam proses pembelajaran Bahasa Indonesia pada materi pokok menulis puisi.

\section{Persentase (\%) Rata-rata Rekapitulasi Ketuntasan Hasil Tes Kemampuan}

Menulis Puisi Siswa

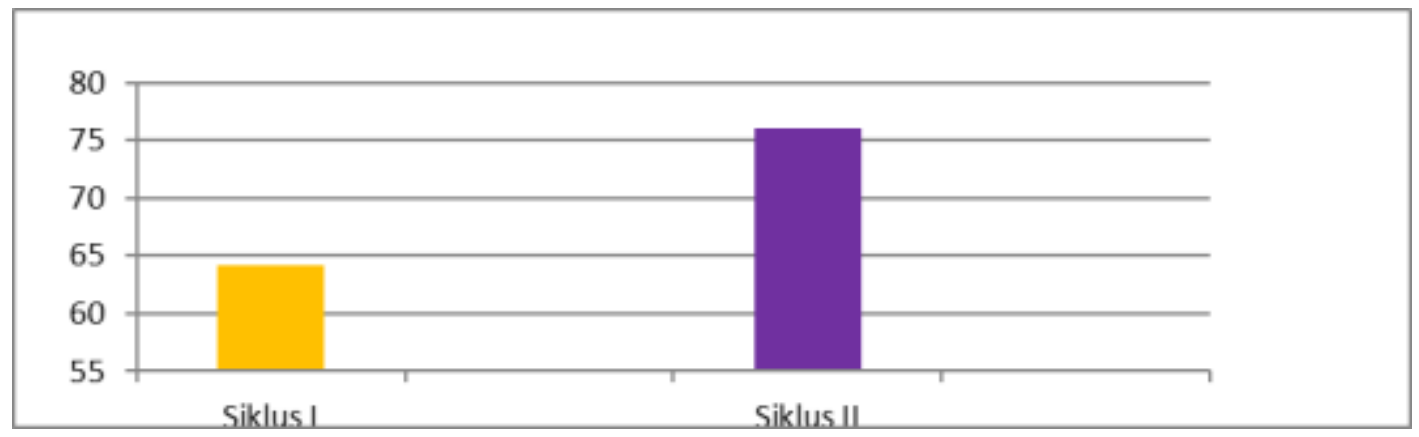

Persentase (\%) Hasil Pretest, Siklus I dan Siklus II

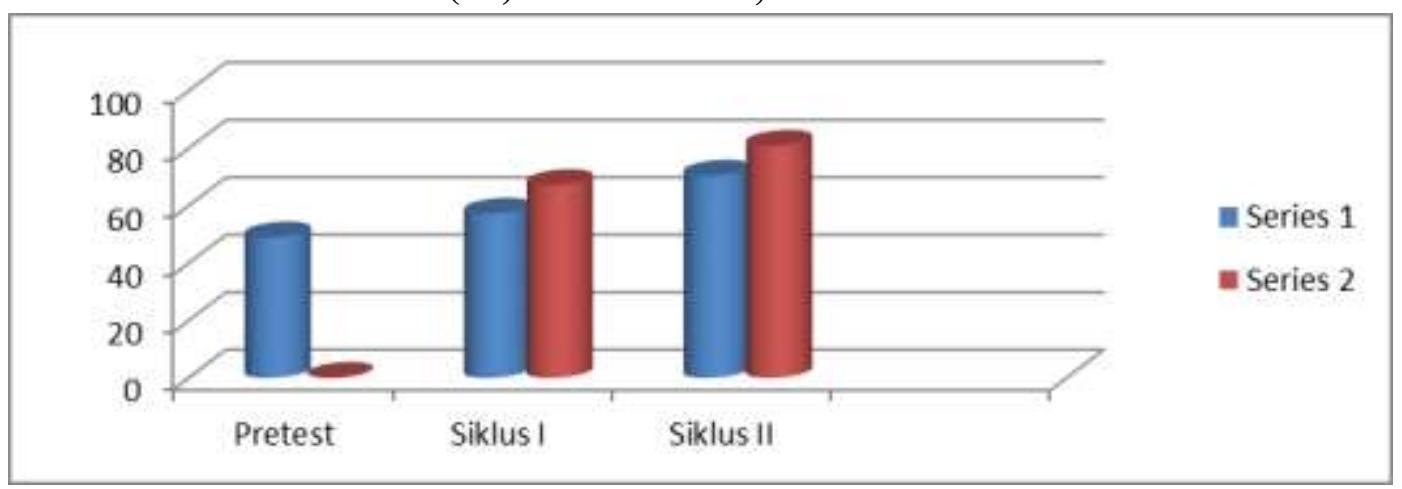

\subsection{Persentase Aktivitas Siswa Secara Klasikal Pada Siklus I dan II}




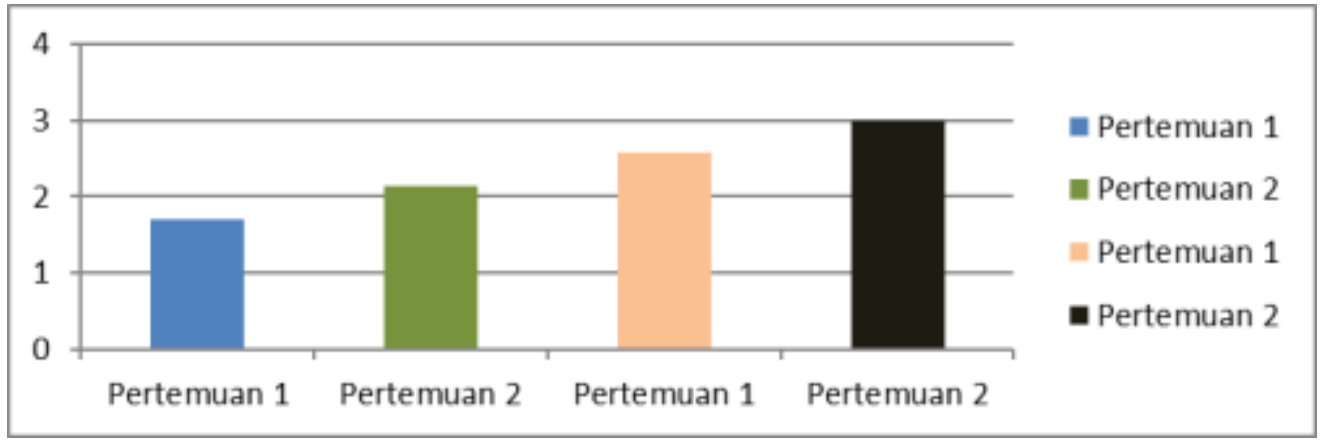

Persentase Hasil Observasi Kegiatan Guru Pada Siklus I dan II

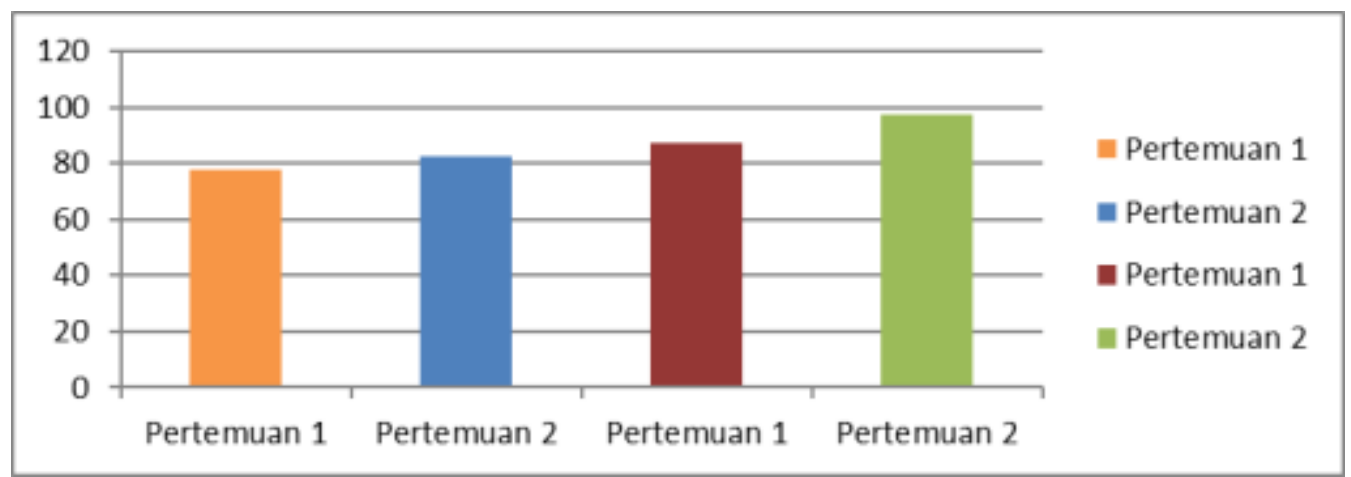

\section{SIMPULAN}

Berdasarkan

hasil

pengamatan dan data yang dilakukan terhadap Bpeningkatan kemampuan menulis puisi siswa pada materi menulis puisi dengan menggunakan metode CIRC (Cooperative, Integrated, Reading, And Composition) di Kelas V SD Negeri No. 104247 Tanjung Mulia, maka peneliti membuat kesimpulan sebagai berikut :

1. Pada siklus I peningkatan kemampuan menulis puisi siswa sudah mulai tampak, namun belum dikatakan berhasil karena masih banyak siswa yang belum tuntas. Peningkatan kemampuan menulis puisi pada siklus I ada 1 orang siswa $(4,34 \%)$ yang memperoleh kriteria sangat mampu, 9 orang siswa $(39,13 \%)$ yang memperoleh kriteria mampu, terdapat 13 orang siswa $(56,12 \%)$ yang memperoleh kriteria cukup mampu dan sudah tidak ada lagi siswa yang belum mampu menulis.

2. Pada siklus II peningkatan kemampuan menulis siswa sudah tampak dan sudah bisa dikatakan berhasil, karena ada 12 orang siswa yang memiliki kriteria sangat mampu $(52,17 \%)$, 11 orang siswa yang memiliki kriteria mampu $(47,82 \%)$, sudah tidak ada lagi siswa yang memperoleh kriteria cukup mampu dan belum mampu menulis.

3. Hasil pengamatan aktivitas siswa belajar siswa secara 
klasikal mengalami peningkatan sebagai berikut: pada siklus I pertemuan 1 dan 2, nilai rata-rata lembar observasi adalah 2,14 yang dikategorikan baik. Pada siklus II pertemuan 3 dan 4 meningkat dengan rata-rata 3,21 yang dikategorikan sangat baik.

4. Hasil pengamatan lembar observasi guru dalam menerapkan metode CIRC (Cooperative, Integrated, Reading, And Composition) juga mengalami peningkatan sebagai berikut pada siklus I pertemuan 1 dan 2, nilai rata-rata lembar observasi adalah 8,0. Pada siklus II pertemuan 1 dan 2 meningkat dengan nilai rata-rata mencapai 92,5 .

5. Dengan menggunakan metode CIRC (Cooperative, Integrated, Reading, And Composition) dapat meningkatkan kemampuan menulis puisi siswa.

Berdasarkan hasil penelitian ini, maka peneliti mengemukakan saran bagi para guru agar menerapkan metode pembelajaran yang dapat meningkatkan kemampuan menulis puisi siswa untuk meningkatkan kegiatan pembelajaran yang berlangsung. Salah satu metode guru untuk meningkatkan kemampuan menulis siswa adalah metode CIRC (Cooperative, Integrated, Reading, And Composition).

\section{DAFTAR RUJUKAN}

Aminuddin, 2015. Pengantar Apresiasi Karya Sastra, Bandung: Sinar Baru Algensindo.

Dalman, 2014. Keterampilan Menulis, Jakarta: Grafindo Persada

Dewi, $\quad$ Rasmala. 2015. Profesionalisasi Guru Melalui Penelitian Tindakan Kelas, Medan: Unimed Press.

Djamarah, Syaiful Bahri. Zain, Azwan. 2010. Strategi Belejar Mengajar. Jakarta: Rineka Cipta.

Hamalik, Oemar. 2010. Proses BelajarMengajar.

Jakarta:Bumi Aksara .

Hamdani.2011. Strategi Belajar Mengajar. Bandung: Pustaka Setia.

Huda, Miftahul. 2014. Model-model Pengajaran dan Pembelajaran, Yogyakarta: Pustaka Belajar.

Istarani, 2015. 58 Model Pembelajaran Inovatif, Medan; Iscom Medan.

Kosasih, 2017. Ketatabahasaan dan Kesustraan, Bandung: Cv. Yrama Widya Bandung.

Kurniasih, Imas. 2016. Ragam Pembelajaran Model

Pembelajaran. Jakarta: Kata Pena.

Mafrukhi, 2007. Saya Senang Berbahasa Indonesia Kelas V, Jakarta: Erlangga.

Sadirman, 2016. Interaksi dan Motivasi Belajar Mengajar, Jakarta: Raja Grafindo. 
Sihotang, Ellys. 2017. "Peningkatan

Keterampilan Menulis Paragraf

Melalui Penerapan Kegiatan

Menulis Jurnal Untuk

Penilaian Autentik Pada Siswa

Kelas VIII SMP Negeri 5

Tebing Tinggi" School

Education Journal Vol.7,

No.4. hlm 515-524.

Simanjuntak, Eva \& Dewi ana. 2015,

"Meningkatkan Kemampuan

Membaca Siswa Dengan

Menggunakan Metode Speed

Reading Pada Mata Pelajaran

Bahasa Indonesia Di Kelas V

SDN 014610 Sei Renggas"

Jurnal Handayani, Vol.3, No.1

hlm 12-21.

Simanjuntak, Eva \& Lili Husaini,

2017. "Meningkatkan

Kemampuan Menulis Dalam

Pembelajaran Bahasa

Indonesia Melalui Model

Example Non Example Di

Kelas V Sekolah Dasar Negeri

Medan" School Education

Jurnal Vol.7, No.1. hlm 8-17

Sudjana, nana 2016. Penilaian

Proses Hasil Belajar

Mengajar. Bandung : Remaja

Rosdakarya.

Suprijono, Agus. 2010. Cooperative

Learning. Yogyakarta :Pustaka

Belajar.

Tarigan, Henry. 2013. Menulis

Sebagai Suatu Keterampilan

Berbahasa. Bandung: Angkasa

Bandung.

Waluyo, Herman. 2005. Apresiasi

Puisi. Jakarta: Gramedia

Pustaka Utama. 